\title{
High morpholine degradation rates and formation of cytochrome P450 during growth on different cyclic amines by newly isolated Mycobacterium sp. strain HE5
}

\author{
Thomas Schräder, Grit Schuffenhauer, Bernhard Sielaff \\ and Jan R. Andreesen
}

Institut für Mikrobiologie, Martin-Luther-Universität Halle, Kurt-Mothes-Str. 3, D-06099 Halle, Germany
Author for correspondence: Jan R. Andreesen. Tel: +49 345 5526350. Fax: + 493455527010. e-mail: j.andreesen@mikrobiologie.uni-halle.de

Using morpholine as sole source of carbon, nitrogen and energy, strain HE5 (DSM 44238) was isolated from forest soil. The isolated strain was identified as a member of the subgroup of fast-growing Mycobacterium species as revealed by 165 rDNA analysis. An identity of $99.4 \%$ was obtained to Mycobacterium gilvum; however, the type strain was unable to utilize morpholine. A maximal growth rate of $0.17 \mathrm{~h}^{-1}$ was observed at a morpholine concentration of $30 \mathrm{mM}$, $30{ }^{\circ} \mathrm{C}$ and $\mathrm{pH} \mathrm{7 \cdot 2}$. The substrate was tolerated at concentrations up to $100 \mathrm{mM}$. Besides morpholine, the strain utilized pyrrolidine, piperidine and proposed intermediates in morpholine metabolism such as glycolate, glyoxylate and ethanolamine. Degradation of morpholine, piperidine and pyrrolidine by resting or permeabilized cells was strictly dependent on the presence of oxygen. Addition of the cytochrome-P450-specific inhibitor metyrapone to the growth medium resulted in a significantly decreased growth rate if these cyclic amines were used as a substrate. Carbon monoxide difference spectra of crude extracts from cells grown on these substrates compared to spectra obtained for extracts of succinate-grown cells indicated that cytochrome P450 is specifically expressed during growth on the cyclic amines. These data indicated that a cytochrome-P450-dependent monooxygenase is involved in the degradation of the three cyclic amines.

Keywords: morpholine, cyclic amines, degradation, Mycobacterium, cytochrome P450

\section{INTRODUCTION}

The heterocyclic xenobiotic compound morpholine is of great importance for different industrial purposes (Mijos, 1978). It is used as a versatile solvent, rubber additive, anticorrosive agent and in the production of drugs and pesticides due to its chemical nature, being both a cyclic ether and a secondary amine. Because of its wide range of applications, morpholine occurs in the environment and has been detected in foods (Hamano et al., 1981; Mohri, 1987). Like other secondary amines, morpholine is subject to chemical and biological $\mathrm{N}$ nitrosation, thus becoming a carcinogenic compound (Enzmann et al., 1995). The removal of morpholine from contaminated industrial waste waters is therefore

The EMBL accession number of the 16S rRNA gene of Mycobacterium sp. strain HE5 is AJ012738. of environmental interest. The isolated organisms capable of growing on morpholine as sole source of carbon, nitrogen and energy were identified in most cases as mycobacteria (Cech et al., 1988; Knapp \& Brown, 1988; Swain et al., 1991; Poupin et al., 1998), with the exception of an Arthrobacter sp. (Dmitrenko et al., 1985). More recently, Knapp et al. (1996) described some Gram-negative Pseudomonas spp. co-metabolizing morpholine in the presence of succinate. A common feature of morpholine-utilizing cultures is their slow growth $\left(\mu_{\max } 0.05-0.07 \mathrm{~h}^{-1}\right)$, disadvantageous for potential biotechnological applications (Knapp et al., 1982; Cech et al., 1988; Knapp \& Brown, 1988; Mazure \& Truffaut, 1994; Poupin et al., 1996, 1998).

Hypothetical pathways have been proposed for the microbial biodegradation of morpholine (Swain et al., 1991; Mazure \& Truffaut, 1994; Combourieu et al., 1998). Depending on the organism studied, ethanola- 
mine and glycolate were suggested to be key intermediates in the biodegradation of morpholine (Swain et al., 1991; Combourieu et al., 1998). Combourieu et al. (1998) used ${ }^{1} \mathrm{H}$ NMR spectroscopy for a direct detection of morpholine and they were able to identify 2-(2aminoethoxy)acetate as an intermediate of morpholine degradation, demonstrating that the initial ring cleavage occurred at the $\mathrm{C}-\mathrm{N}$ bond. However, little is known about the enzymes catalysing these initial steps (Knapp et al., 1982; Cech et al., 1988; Knapp \& Brown, 1988; Brown \& Knapp, 1990; Swain et al., 1991; Emtiazi \& Knapp, 1994; Mazure \& Truffaut, 1994). Recently, evidence was presented for a cytochrome P450 to be involved in the initial oxidation of morpholine by an environmental Mycobacterium strain (Poupin et al., 1998).

In this paper, we describe the isolation and characterization of a Mycobacterium strain related to Mycobacterium gilvum showing significantly increased morpholine degradation rates compared to the morpholine-utilizing organisms described so far. Evidence is presented that a cytochrome P450 is involved in morpholine, piperidine and pyrrolidine degradation by this organism.

\section{METHODS}

Chemicals. Cyclic amines, ethanolamine, aminoethoxyethanol, DTT and PMSF were purchased from Sigma. Q Sepharose was obtained from Pharmacia and Benzonase was from Merck. All chemicals were at least of analytical-reagent grade.

Enrichment, isolation and growth of organisms. Aerobic morpholine-degrading organisms were isolated from noncontaminated forest soil samples. The inocula were suspended in flasks containing $10 \mathrm{ml}$ mineral salts medium and incubated at $30^{\circ} \mathrm{C}$ for $1-4$ weeks. The medium consisted of $0.09 \mathrm{mM}$ $\mathrm{CaCl}_{2}, 0.06 \mathrm{mM} \mathrm{MnSO}$, $0.85 \mathrm{mM} \mathrm{NaCl}, 2.0 \mathrm{mM} \mathrm{MgSO}$, $100 \mathrm{mM}$ potassium phosphate ( $\mathrm{pH} 7 \cdot 2$ ), $5 \mathrm{ml}$ vitamin solution (Genthner et al., 1981), $1 \mathrm{ml}$ trace element solution (Hormann \& Andreesen, 1989) and $20 \mathrm{mM}$ morpholine as carbon and nitrogen source. In experiments when no nitrogen was supplied with the carbon source tested, $5 \cdot 6 \mathrm{mM} \mathrm{NH}_{4} \mathrm{Cl}$ was added to the medium. Serial dilutions of the obtained cultures were plated on mineral agar plates (containing $2 \%$ agar) and incubated at $30^{\circ} \mathrm{C}$ for $15-25 \mathrm{~d}$. Subsequently, single colonies were transferred again into mineral salts medium. Pure cultures of morpholine-degrading bacteria were obtained by repeating this procedure twice. The fastest growing culture, designated strain HE5, was chosen for the investigations reported in this study and deposited at the DSMZ (Braunschweig, Germany) under the accession number DSM 44238. Mass cultures were grown in baffled flasks (2-5 l) shaken at 130 r.p.m. Growth was followed as the increase in $\mathrm{OD}_{600}$.

The substrate range of the isolated Mycobacterium sp. and the inhibition of growth on morpholine, pyrrolidine and piperidine by metyrapone were investigated by adding the corresponding compounds to mineral salts medium.

Identification of the isolated organism. Morphological properties of the isolated organism were determined by phase- contrast microscopy. Gram staining, acid- and alcoholfastness, catalase and oxidase activity and pigment production were investigated according to standard procedures. The $\mathrm{G}+\mathrm{C}$ content of the isolated DNA was determined as described by Tamaoko \& Komagata (1984). Analysis of fatty acids was performed as reported by Häggblom et al. (1994). Genomic DNA from a single colony of strain HE5 served as a template for PCR. Universal primers fD1 and rD1 were used for amplification of the $16 \mathrm{~S} \mathrm{rDNA}$ (Weisburg et al., 1991). The obtained PCR product was purified and ligated into the pGEM-T vector (Promega). After transformation into Escherichia coli XL2-Blue and subsequent isolation of the plasmid vector, sequencing was carried out by using an ALF sequencer (Pharmacia) and the Cycle sequencing kit (Pharmacia). Analysis of the obtained sequence was performed by the DNASIS program and the FASTA 3 program using the EPRO database.

Determination of substrate and intermediate concentrations. During growth of the organism, the concentration of morpholine in the mineral salts medium was determined by a colorimetric assay using naphthoquinone sulfonic acid (Knapp et al., 1982). Alternatively, the concentration of morpholine and other growth substrates was estimated by GC analysis using a gas chromatograph 14-B (Shimadzu), a flameionization detector and capillary column BGB-1701 (SCP Seitz, length $30 \mathrm{~m}$, inside diameter $0 \cdot 25 \mathrm{~mm}$, film thickness $0 \cdot 25$ $\mu \mathrm{m})$. The secondary amines were derivatized with benzenesulfonyl chloride before analysis (Hamano et al., 1981). The conditions set at the GC were: column temperature $200^{\circ} \mathrm{C}$, injector temperature $280^{\circ} \mathrm{C}$, detector temperature $240{ }^{\circ} \mathrm{C}$, helium carrier gas at a flow rate of $40 \mathrm{~cm} \mathrm{~s}^{-1}$ and a split of $1: 20$. The concentration of ammonia was estimated by a coupled enzymic assay using glutamate dehydrogenase (Boehringer).

Preparation and separation of crude extracts. After addition of $3 \mu$ l Benzonase (Benzonuclease) per $10 \mathrm{ml}$ suspension and $10 \mu \mathrm{M}$ PMSF, the washed cells were disrupted by passing them three times through a French press at $110 \mathrm{MPa}$. The cell debris and membranes were removed by centrifugation at $33000 \mathrm{~g}$ for $20 \mathrm{~min}$ and $120000 \mathrm{~g}$ for $1 \mathrm{~h}$, respectively. The obtained supernatant, designated crude extract, was applied to a $\mathrm{Q}$ Sepharose column previously equilibrated with $50 \mathrm{mM}$ potassium phosphate buffer, $\mathrm{pH} 8.5$ (buffer A). Unbound protein was washed off with 3 vols buffer $A$ and subsequently the bound protein was eluted by a linear gradient from 0 to $1 \mathrm{M}$ $\mathrm{NaCl}$ in buffer A. Protein was determined according to Bradford (1976) using bovine serum albumin as a standard.

Spectral and polarographic measurements. The carbon monoxide difference spectra were recorded with a Uvikon 930 spectrophotometer (Kontron, Eching) using crude extract previously reduced by the addition of dithionite $(2 \mathrm{mM})$. Carbon monoxide was bubbled through the cuvette and reduced extracts without carbon monoxide were used as reference. The morpholine-dependent oxygen consumption was determined polarographically using a Clark electrode (Rank Brothers).

\section{RESULTS}

\section{Isolation and characterization of the morpholine- degrading strain}

The morpholine-degrading strain used in this study was isolated from forest soil samples collected near Göttingen (Germany). The growth rate of the obtained 


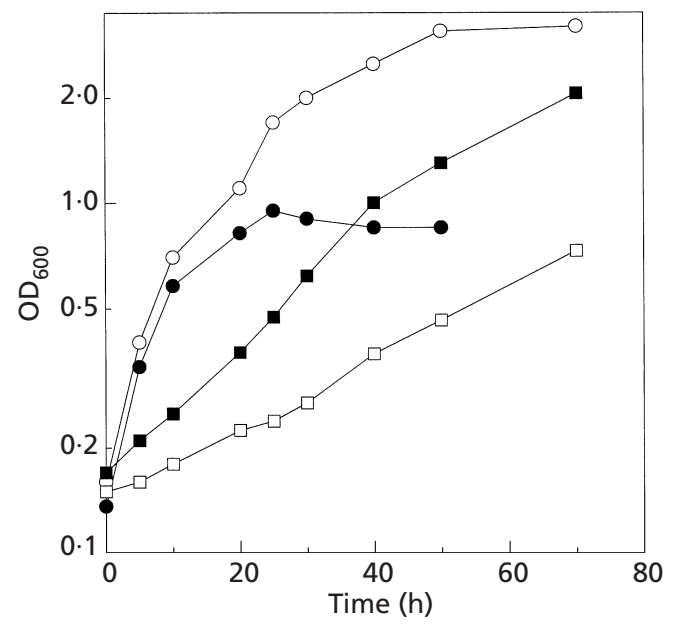

Fig. 1. Growth of Mycobacterium sp. strain HE5 in mineral salts medium containing $5 \mathrm{mM}(0), 30 \mathrm{mM}(\bigcirc), 60 \mathrm{mM}(\boldsymbol{\square})$ and $100 \mathrm{mM}(\square)$ morpholine.

pure cultures was investigated and the fastest growing organism, designated strain HE5, was used for further studies. This strain was characterized as a Grampositive, catalase-positive, oxidase-negative, acid-fast, alcohol-fast, non-spore-forming, rod-shaped, thermosensitive bacterium. The DNA G $+\mathrm{C}$ content of the relatively fast-growing, orange-coloured, scotochromogenic organism was estimated to be $69 \mathrm{~mol} \%$. Analysis of the fatty acid pattern of the membrane led to the identification of 10-methyloctadecanoic acid (11\%), which is typical of the genera Rhodococcus, Nocardia, Gordona and Mycobacterium (Kroppenstedt, 1985). These combined data indicated that the isolated organism belongs to the genus Mycobacterium. The cellular fatty acid pattern of Mycobacterium sp. strain HE5 revealed no significant similarities to the 27 patterns from different mycobacteria deposited at the MIS Library database for Mycobacteria. To obtain further information on the isolated organism, the complete sequence of the $16 \mathrm{~S}$ rRNA gene was determined and deposited at the EMBL database under accession number AJ012738. The results obtained by sequence analysis confirmed the conclusion that strain HE5 belongs to the fast-growing, thermosensitive mycobacteria. The isolated strain shared with the fast-growing mycobacteria the lack of an extended helix structure at position 451-482 (E. coli numbering) (Stahl \& Urbance, 1990). A second signature sequence located at position 184-193 (E. coli numbering) can be used for a discrimination between thermotolerant and thermosensitive mycobacteria (Rogall et al., 1990; Stahl \& Urbance, 1990) and Mycobacterium sp. strain HE5 showed a high similarity to the latter physiological group. The highly variable region between positions 175 and 238 (E. coli numbering) containing possible species-specific regions (Böddinghaus et al., 1990) showed 100\% identity to the corresponding sequence of M. gilvum. A comparison of the almost complete 16S rDNA sequence from Myco- bacterium sp. strain HE5 to the EMBL database revealed the highest similarity to different members of the fastgrowing mycobacteria. A binary similarity value of $99 \cdot 4$, 98.7 and $98.3 \%$ was determined to the sequences from M. gilvum, Mycobacterium parafortuitum and Mycobacterium chlorophenolicum, respectively. Growth experiments carried out with the type strain of $M$. gilvum (DSM 44245) under the same conditions described for Mycobacterium sp. strain HE5 showed that the type strain was not able to grow on morpholine, piperidine or pyrrolidine ( $20 \mathrm{mM}$ each).

\section{Growth of Mycobacterium sp. strain HE5}

During investigations of the influence of $\mathrm{pH}$, temperature and morpholine concentration on growth of Mycobacterium sp. strain HE5, optimal growth was obtained at a substrate concentration of $30 \mathrm{mM}$ at $30^{\circ} \mathrm{C}$ and $\mathrm{pH} 7 \cdot 2$ (Fig. 1). Under these conditions, the maximal growth rate was determined at $0 \cdot 17 \mathrm{~h}^{-1}$. The growth rate halved at a morpholine concentration of $45 \mathrm{mM}$ and decreased to 0.041 or $0.023 \mathrm{~h}^{-1}$, respectively, if the morpholine concentration was increased to 60 or $100 \mathrm{mM}$ (Fig. 1). However, $70 \%$ of the initial morpholine was still degraded if the strain was grown at a substrate concentration of $100 \mathrm{mM}$ (data not shown). No growth occurred if morpholine was omitted from the medium. Mycobacterium sp. strain HE5 degraded $90 \pm 5 \%$ of the initial morpholine $(30 \mathrm{mM})$ during the exponential growth phase, whereas the remaining substrate was utilized during the stationary phase. The yield obtained under these conditions was $0.48 \mathrm{~g}$ cell dry weight per $g$ substrate utilized. If the organism was grown in the presence of $60 \mathrm{mM}$ morpholine the substrate concentration decreased by $40 \mathrm{mM}$ within $48 \mathrm{~h}$. During this time, the turbidity of the culture increased from 0.4 to about 6.0 (Fig. 2). The morpholinedegradation rate determined under optimal growth conditions $\left(30 \mathrm{mM}\right.$ morpholine, $30^{\circ} \mathrm{C}$, $\left.\mathrm{pH} 7 \cdot 2\right)$ was 0.84 $\mathrm{mmol} \mathrm{g}^{-1}$ (dry wt) $\mathrm{h}^{-1}$. No loss of morpholine was observed under the same conditions in the absence of bacterial cells. Taking all these data together, it is obvious that Mycobacterium sp. strain HE5 has a much higher morpholine-degrading capacity than the morpholine-utilizing organisms described so far, Mycobacterium aurum MO1, Mycobacterium sp. MorG and Mycobacterium sp. RP1 (Knapp et al., 1982; Mazure \& Truffaut, 1994; Poupin et al., 1998).

As observed for other morpholine-degrading organisms, Mycobacterium sp. strain HE5 released ammonia into the medium during growth on this substrate. At a substrate concentration of $60 \mathrm{mM}$ the molar ratio of morpholine degraded to ammonia produced was found to be $1: 0 \cdot 5$ (Fig. 2). A similar stoichiometry was obtained at 20,30, 40 and $50 \mathrm{mM}$ morpholine, being different to the ratio of 1:0.82 and 1:0.94 determined for M. aurum MO1 and strain MorG, respectively (Knapp et al., 1982; Mazure \& Truffaut, 1994; Swain et al., 1991). Growth of Mycobacterium sp. strain HE5 was not inhibited by the addition of ammonia (up to $40 \mathrm{mM}$ ) to 


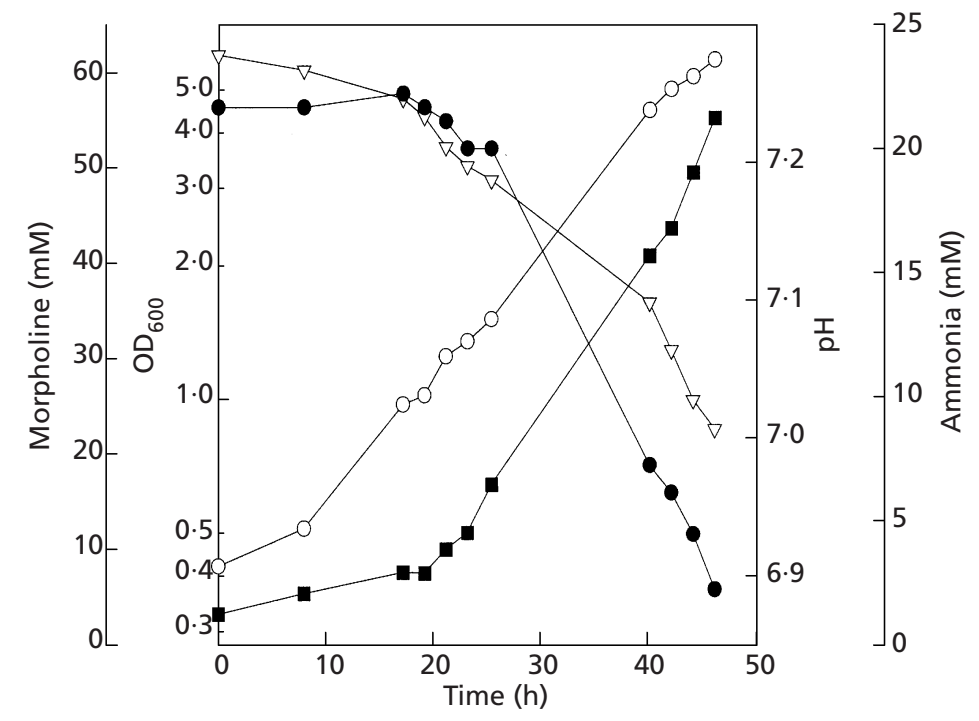

Fig. 2. Optical density (O), morpholine degradation $(\nabla)$, ammonia accumulation (ם) and changes in $\mathrm{pH}(\boldsymbol{O})$ during growth of Mycobacterium sp. strain HE5 in mineral salts medium containing $60 \mathrm{mM}$ morpholine.

the morpholine-containing mineral salts medium. Ammonia concentrations higher than $50 \mathrm{mM}$ seem not to be relevant under physiological growth conditions but can be reached during growth on morpholine in batch-fed cultures (Mazure \& Truffaut, 1994).

Mycobacterium sp. strain HE5 was able to grow on the heterocycles pyrrolidine and piperidine, whereas no growth occurred in the presence of the substituted morpholine derivatives $\mathrm{N}$-formyl-, $\mathrm{N}$-methyl-, $\mathrm{N}$-ethylmorpholine, 2-morpholinoethanol or piperazine. As shown by the succinate-grown control used in Fig. 3, the ability to grow on pyrrolidine (Fig. 3) was delayed, as a lag phase of about $7.5 \mathrm{~h}$ was observed. A similar delay of growth was obtained if succinate-grown cells were transferred to a piperidine- or morpholine-containing medium (data not shown). Interestingly, no lag phase was observed if cells grown on morpholine (Fig. 3) or piperidine (data not shown) were transferred to a pyrrolidine-containing mineral salts medium, indicating that the pathway of pyrrolidine degradation was turned on by these substrates. However, a lag phase $(9 \mathrm{~h})$ was observed for growth of strain HE5 on morpholine or piperidine using cells pregrown on pyrrolidine (data not shown), and also growth on piperidine led to a delayed morpholine degradation, indicating a substrate-specific step.

Further growth substrates utilized by the organism were different organic acids and amino acids such as acetate, pyruvate, succinate, glycine, L-alanine, L-serine, Lproline and L-lysine and the proposed intermediates in morpholine catabolism: glycolate, glyoxylate and ethanolamine. 2-Hydroxymorpholine, the proposed hydroxylated ring product in morpholine degradation, 2-(2-aminoethoxy)acetaldehyde (as the open form of the latter) as well as 2-(2-aminoethoxy)acetate as the next proposed intermediate (Poupin et al., 1998) are not commercially available. Thus the degradation of these compounds could not be investigated. Mycobacterium

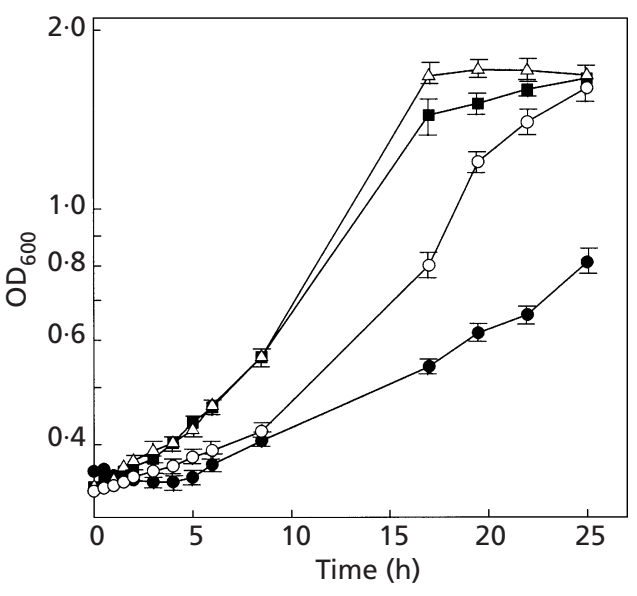

Fig. 3. Induction of pyrrolidine degradation by morpholine. Cells were grown on $20 \mathrm{mM}$ morpholine and transferred to mineral salts medium containing $20 \mathrm{mM}$ pyrrolidine $(\triangle)$, morpholine ( $\boldsymbol{\square}$ ) or piperidine $(\boldsymbol{)})$ as sole carbon and nitrogen source. A similar induction of pyrrolidine degradation was obtained if Mycobacterium HE5 was pregrown on piperidine instead of morpholine. Succinate-grown cells transferred to a mineral salts medium containing pyrrolidine were used as a control $(O)$. The lag phase obtained with succinate-grown cells on pyrrolidine medium was similar for morpholine and piperidine.

sp. strain HE5 was unable to grow on the commercially available substances 2-(2-aminoethoxy)ethanol (from which the above-mentioned corresponding aldehyde or acid might be formed) or 2-(2-aminoethylamino)ethanol. 2-(2-Aminoethoxy)acetate was suggested to be split to glycolate and aminoacetaldehyde (Swain et al., 1991; Combourieu et al., 1998; Poupin et al., 1998). Morpholine-grown cells of Mycobacterium sp. strain HE5 showed good growth without any lag phase if they were transferred to a glycolate- or glyoxylate-containing 


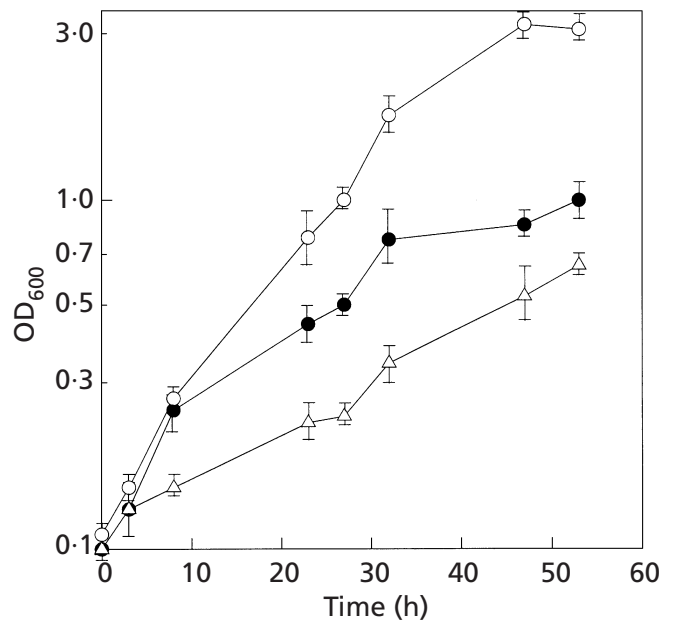

Fig. 4. Growth of Mycobacterium sp. strain HE5 on proposed intermediates in morpholine degradation. The organism was pregrown on $20 \mathrm{mM}$ morpholine and transferred to mineral salts medium containing (20 mM each) morpholine (O), glyoxylate $(\triangle)$ or glycolate $(\mathbf{O})$

medium (Fig. 4). Growth on the more oxidized compound glyoxylate was significantly slower than determined for glycolate. Ethanolamine was utilized after an extended adaptation phase of more than $50 \mathrm{~h}$ (data not shown). If cells were pregrown on succinate, an extended lag phase was also observed after transfer to a glycolate- or glyoxylate-containing medium (data not shown).

\section{Investigations on the initial reaction in morpholine degradation}

The primary aim for these investigations was the detection of an enzymic activity catalysing the initial step in morpholine degradation. Very recently, evidence was presented that Mycobacterium sp. RP1 induces a cytochrome P450 during growth on morpholine (Poupin et al., 1998). Thus a monooxygenase might be involved in the initial step of morpholine degradation. No morpholine-dependent oxygen consumption could be detected in crude extracts of Mycobacterium sp. strain HE5 prepared from morpholine-grown cells under aerobic or anaerobic conditions. The addition of $\mathrm{NAD}(\mathrm{P}) \mathrm{H}$ and FAD or FMN and/or DTT and/or Fe ${ }^{2+}$ to the assay mixtures of different $\mathrm{pH}$ values $(5 \cdot 0-10 \cdot 0)$ containing $0 \cdot 1-20 \mathrm{mM}$ morpholine had no influence on the oxygen consumption. These results could be explained by either a low stability of the corresponding activity or the non-involvement of an oxygenase reaction in the initial substrate conversion as previously proposed (Swain et al., 1991). However, no morpholine-dependent dehydrogenase activity could be detected in extracts of Mycobacterium sp. strain HE5 (Schuffenhauer et al., 1999). Based on the negative results obtained with cell extracts, we investigated resting or permeabilized cells for their morpholine-utilizing ability, comparing aerobic

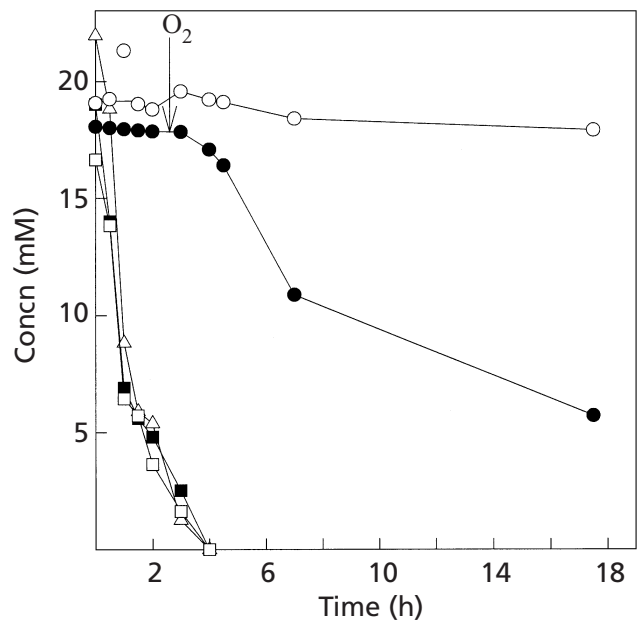

Fig. 5. Degradation of cyclic amines by permeabilized cells of Mycobacterium sp. strain HE5. Cells were grown on the investigated substrates and permeabilized by freezing for $15 \mathrm{~h}$ at $-20^{\circ} \mathrm{C}$ in $50 \mathrm{mM}$ potassium phosphate buffer, $\mathrm{pH} 7 \cdot 2$, containing $0 \cdot 1 \%$ Triton $\mathrm{X}-100$. The degradation of pyrrolidine $(\square)$, piperidine $(\triangle)$ and morpholine $(\square)$ under aerobic conditions was determined by GC analysis. Furthermore, morpholine degradation was analysed under anaerobic conditions $(\boldsymbol{O})$ and subsequent addition of oxygen as indicated. Mineral salts medium containing morpholine but no cells was used as a control $(\bigcirc)$.

and anaerobic conditions and using GC analysis. Both resting or permeabilized cells of Mycobacterium sp. strain HE5 completely degraded the cyclic amines morpholine, piperidine and pyrrolidine. If oxygen was present, permeabilized cells were able to degrade each of the cyclic amines $(20 \mathrm{mM})$ within $4 \mathrm{~h}$ (Fig. 5). Under anaerobic conditions, only $7 \%(1.4 \mathrm{mM})$ of the initial amount of, for example, morpholine was removed within $3 \mathrm{~h}$ from the supernatant. However, a subsequent addition of oxygen led to a resumed substrate removal (Fig. 5). In addition, a morpholine-dependent oxygen consumption was observed using permeabilized cells. However, the oxygen consumption rate was threefold lower than determined with resting cells. These data indicated that an oxygenase might be involved in morpholine degradation. However, the activity of this enzyme seems to be very labile and extremely sensitive to the disruption of the native cell structure.

Metyrapone is regarded as a specific inhibitor of P450dependent enzymes (Testa \& Jenner, 1981). Therefore, we investigated the influence of this compound on the growth of Mycobacterium sp. strain HE5. Addition of metyrapone $(2 \mathrm{mM})$ resulted in a significant inhibition of growth which was quite similar if morpholine (Fig. 6), pyrrolidine or piperidine (data not shown) was used as a substrate. However, cells grown on succinate were only retarded in their growth rate by metyrapone (Fig. 6). These data pointed to an involvement of a cytochrome $\mathrm{P} 450$ in the degradation of morpholine and the other cyclic amines by Mycobacterium sp. strain HE5. Furthermore, carbon monoxide difference spectra were 


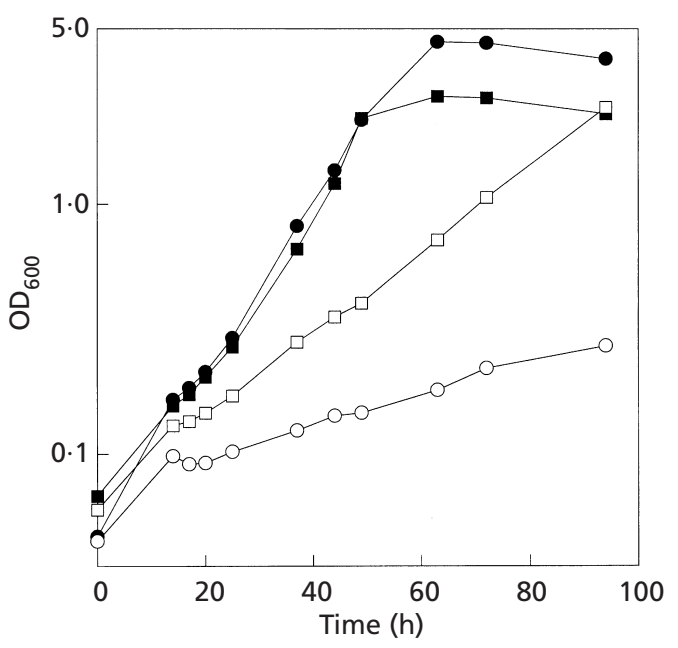

Fig. 6. Inhibitory effect of metyrapone on Mycobacterium sp. strain HE5 during growth on different substrates. The strain was grown on morpholine $(30 \mathrm{mM})$ in the presence $(\bigcirc)$ or absence (0) of metyrapone $(2 \mathrm{mM})$ or on succinate in the presence $(\square)$ or absence ( $\square$ ) of the inhibitor. A similar inhibition to that observed during growth on morpholine was determined if Mycobacterium HE5 was grown on pyrrolidine or piperidine.

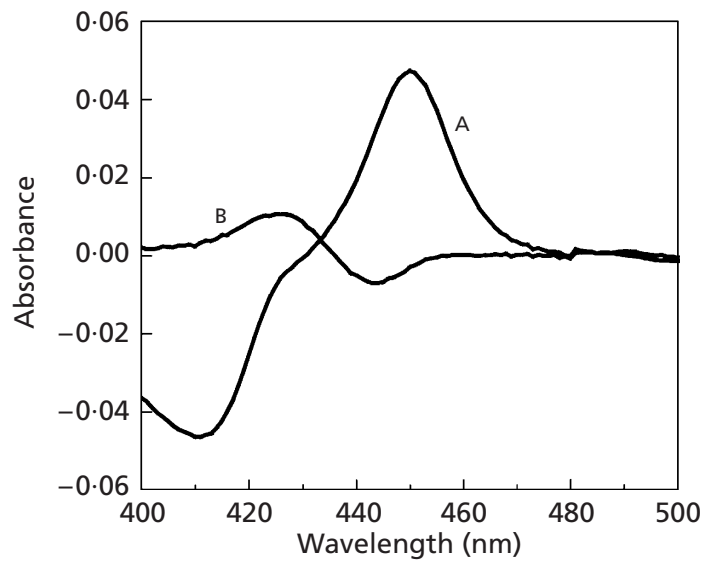

Fig. 7. Carbon monoxide difference spectra of cell extracts prepared from morpholine- (A) and succinate-grown (B) cells of Mycobacterium sp. strain HE5. Spectra similar to that in A were obtained from pyrrolidine- and piperidine-grown cells.

recorded from dithionite-reduced crude extracts of Mycobacterium sp. strain HE5 cells grown on succinate, morpholine (Fig. 7), pyrrolidine and piperidine (data not shown). These spectra indicated that the organism produces a cytochrome P450 during growth on morpholine, pyrrolidine and piperidine which was not detected in extracts from succinate-grown cells. During incubation at room temperature the peak at $450 \mathrm{~nm}$ shifted to $420 \mathrm{~nm}$ (data not shown). This shift is a common feature of cytochrome P450s (Martinis et al., 1996) and thus confirmed the presence of this class of enzyme in extracts from cells grown on the cyclic amines. From these data it can be concluded that the organism expresses at least a similar cytochrome-P450-dependent enzyme system involved in the degradation of the three cyclic amines.

Extracts from morpholine-, piperidine-, pyrrolidineand succinate-grown cells were fractionated by chromatography on Q Sepharose at $\mathrm{pH} 8 \cdot 5$, and the carbon monoxide difference spectrum of each fraction was recorded. A distinct peak based on the difference in $A_{450}$ was only observed in extracts from cells grown on the cyclic amines (data not shown), and not in the control prepared from succinate-grown cells. This suggested that a cytochrome $\mathrm{P} 450$ is expressed during growth of Mycobacterium sp. strain HE5 on each of the three cyclic amines. Furthermore, the elution behaviour of the individual P450 cytochromes varied slightly after separation of the corresponding crude extracts using the same Q Sepharose column. The cytochrome P450 from piperidine-grown cells eluted at a salt concentration of about $0 \cdot 17 \mathrm{M} \mathrm{KCl}$, that from morpholine-grown cells at $0 \cdot 20 \mathrm{M} \mathrm{KCl}$, whereas the cytochrome P450 from pyrrolidine-grown cells was detected at $0.24 \mathrm{M} \mathrm{KCl}$ (data not shown). These results suggested that different P450 cytochromes might be responsible for the initial hydroxylation of these cyclic amines. It is also obvious that carbon monoxide difference spectra might be a useful assay for the purification of the cytochrome P450 induced during growth on morpholine and the other cyclic amines. Therefore, the purification of a cytochrome P450 from morpholine-grown cells became possible and will be published separately.

\section{DISCUSSION}

A Mycobacterium sp. growing on morpholine and other cyclic amines as sole source of carbon, nitrogen and energy was isolated from the environment. According to the $16 \mathrm{~S}$ rDNA, this strain is very closely related to the type strain of M. gilvum. A previously isolated mycobacterial strain able to grow on different polycyclic aromatic hydrocarbons, designated Mycobacterium sp. strain BB1, had a $16 \mathrm{~S}$ rDNA sequence homology of $99.8 \%$ to the corresponding sequence of $M$. gilvum (Boldrin et al., 1993). Recently, the sequence of this organism was reported to be identical to M. gilvum and the obtained nucleotide differences were suggested to be due to sequence errors (Böttger et al., 1997). However, even a $100 \%$ identity cannot be taken as proof that two strains belong to the same species unless DNA-DNA homology studies have been performed (Stackebrandt \& Goebel, 1994). Interestingly, the type strain of $M$. gilvum and strain BB1 are not able to utilize L-alanine as growth substrate (Boldrin et al., 1993), in contrast to Mycobacterium sp. strain HE5, which contains an active L-alanine dehydrogenase (Schuffenhauer et al., 1999). As revealed during our investigations, the type strain of $M$. gilvum was not able to grow on morpholine, piperidine or pyrrolidine. Furthermore, M. gilvum is yellowpigmented in contrast to the orange colour of $\mathrm{Myco-}$ bacterium sp. strain HE5. Thus the isolated strain might be a new species of the fast-growing mycobacteria. Further analysis of Mycobacterium sp. strain HE5 and 
the type strain of M. gilvum is necessary to confirm this suggestion. However, based on all data available, it is obvious that the isolated strain is different from the previously described morpholine-degrading mycobacteria: M. aurum MO1, Mycobacterium sp. MorG, which resembles Mycobacterium chelonae, or strain RP1, being closely related to M. chlorophenolicum (Franklin, 1985; Cech et al., 1988; Combourieu et al., 1998).

The morpholine-degradation rate determined for $\mathrm{Myco-}$ bacterium sp. strain HE5 was about threefold higher than previously determined for M. aurum strain MO1 and strain MorG (Knapp et al., 1982; Cech et al., 1988; Mazure \& Truffaut, 1994). A doubling time of $9 \mathrm{~h}$ was determined for the very recently isolated strain RP1, being about twofold slower than estimated for $\mathrm{Myco-}$ bacterium sp. strain HE5. M. aurum MO1 degrades about $11 \mathrm{mM}$ morpholine within $235 \mathrm{~h}$ and strain RP1 catabolizes $10 \mathrm{mM}$ morpholine within $50 \mathrm{~h}$ (Combourieu et al., 1998; Mazure \& Truffaut, 1994). Thus Mycobacterium HE5 utilizing about 10-15 mM morpholine within $10 \mathrm{~h}$ has by far the highest potential for morpholine degradation and might therefore be useful in biotechnological applications.

The utilization of pyrrolidine and piperidine as growth substrates seems to be a common feature of nearly all morpholine-degrading mycobacteria isolated so far (Mazure \& Truffaut, 1994; Poupin et al., 1998). However, none of the morpholine-degrading organisms was able to grow on piperazine although it was reported in the case of strain MorG that morpholine induces an oxidizing activity of the non-growth substrate piperazine (Knapp et al., 1982). Investigations performed with $M$. aurum MO1 indicated that morpholine did not induce the degradation of pyrrolidine and piperidine in this organism (Mazure \& Truffaut, 1994). Different results were obtained for strain MorG, where morpholine seems to induce the pathway for pyrrolidine degradation (Swain et al., 1991). For Mycobacterium HE5 the degradation pathway of pyrrolidine seems to be induced during growth on morpholine and piperidine but not vice versa.

Depending on the organism investigated, different classes of enzymes were suggested to catalyse the initial oxidation during morpholine degradation (Swain et al., 1991; Poupin et al., 1998). Carbon monoxide difference spectra of extracts from morpholine-, pyrrolidine- and piperidine-grown cells of Mycobacterium sp. RP1 indicated that the organism induces a cytochrome-P450dependent monooxygenase during growth on these substrates (Poupin et al., 1998). This monooxygenase was proposed to be responsible for the initial hydroxylation step in morpholine degradation, leading to the formation of 2-(2-aminoethoxy)acetaldehyde (Poupin et al., 1998). However, a morpholine-dependent enzymic activity could not be detected in Mycobacterium RP1 or strain MorG. Very recently, Poupin et al. (1999) identified a gene encoding a cytochrome P450 involved in piperidine and pyrrolidine utilization by
Mycobacterium smegmatis $\mathrm{mc}^{2} 155$. An involvement of a cytochrome P450 in the initial oxidation of the three cyclic amines was supported by the data that we obtained for Mycobacterium HE5. A cytochrome P450 and a ferredoxin were isolated from Mycobacterium HE5 after growth on morpholine (to be published separately). The cytochrome P450 could only be detected by carbon monoxide difference spectra, not by an enzymic activity. However, using this assay it should be possible to investigate whether individual cytochrome P450s are expressed during growth on each cyclic amine and thus resolve the question of whether the same or different cytochrome P450s are responsible for the conversion of these substrates.

After the initial hydroxylation of morpholine to 2hydroxymorpholine, spontaneous ring opening should occur followed by oxidation of 2-(2-aminoethoxy)acetaldehyde to the corresponding acid. As the next step, the ether bond of 2-(2-aminoethoxy)acetate has to be cleaved. This might be achieved by a second monooxygenase reaction attacking one of the carbon atoms next to the ether bond (White et al., 1996). However, until now nothing has been known about the enzyme catalysing this scission. The involvement of two monooxygenase reactions in morpholine degradation would be in accordance with the lag phase observed during growth of Mycobacterium sp. strain HE5 on morpholine in the case where the cells were pregrown on piperidine or pyrrolidine. Both compounds should not require a second monooxygenase in their degradation pathway. The cleavage of the ether bond was supposed to result in the formation of glycolate in the case of strains MO1, MorG and RP1 (Swain et al., 1991; Combourieu et al., 1998; Poupin et al., 1998). Glycolate will only be formed if the hydroxylation occurs at the amino side of the ether bond of 2-(2-aminoethoxy)acetate, and 2-aminoacetaldehyde will be the second product. The ability of morpholine-grown Mycobacterium HE5 cells to grow on glycolate without any lag phase might indicate that the organism employs a similar pathway in morpholine degradation. Glyoxylate and ethanolamine are proposed intermediates formed if the ether is hydroxylated at the carboxyl side. The formation of ethanolamine from the proposed intermediate 2-aminoacetaldehyde (Swain et al., 1991; Poupin et al., 1998) has not been shown so far. An alternative pathway might be the deamination of 2-(2aminoethoxy)acetate leading after oxidation to the formation of the symmetric ether diglycolate $\left(2,2^{\prime}\right.$-oxydiacetate), subsequently cleaved by a second monooxygenase to glycolate and glyoxylate.

\section{ACKNOWLEDGEMENTS}

We thank Dr U. Lechner and C. Otto of our Institute, who provided data on the fatty acid pattern of the organism and carried out growth studies, respectively. H. Ebner (Institut für Mikrobiologie, University of Göttingen) supplied enrichment cultures of morpholine-degrading organisms. This work was supported by grants from the DECHEMA and the Fonds der Chemischen Industrie. 


\section{REFERENCES}

Böddinghaus, B., Rogall, T., Flohr, T., Blöcker, H. \& Böttger, E. (1990). Detection and identification of mycobacteria by amplification of rRNA. J Clin Microbiol 28, 1751-1759.

Boldrin, B., Tiehm, A. \& Fritzsche, C. (1993). Degradation of phenanthrene, fluorene, fluoranthene, and pyrene by a $\mathrm{Myco-}$ bacterium sp. Appl Environ Microbiol 59, 1927-1930.

Böttger, E. C., Kirscher, P., Springer, B. \& Zumpf, W. (1997). Mycobacteria degrading polycyclic aromatic hydrocarbons. Int J Syst Bacteriol 47, 247.

Bradford, M. M. (1976). A rapid and sensitive method for quantitation of microgram quantities of protein utilizing the principle of protein-dye binding. Anal Biochem 72, 248-254.

Brown, V. R. \& Knapp, J. S. (1990). The effect of withdrawal of morpholine from the influent and its reinstatement on the performance and microbial ecology of a model activated sludge plant treating a morpholine-containing effluent. J Appl Bacteriol 69, 43-53.

Cech, J. S., Hartmann, P., Slosarek, M. \& Chudoba, J. (1988). Isolation and identification of a morpholine degrading bacterium. Appl Environ Microbiol 54, 619-621.

Combourieu, B., Besse, P., Sancelme, M., Verschambre, H., Delort, A. M., Poupin, P. \& Truffaut, N. (1998). Morpholine degradation pathway of Mycobacterium aurum MO1: direct evidence of intermediates by in situ ${ }^{1} \mathrm{H}$ nuclear magnetic resonance. Appl Environ Microbiol 64, 153-158.

Dmitrenko, G. N., Udod, V. M. \& Gvozdyak, P. I. (1985). Degradation of morpholine by immobilised bacteria. Khim Teknol Vody 7, 97-99.

Emtiazi, G. \& Knapp, J. S. (1994). The biodegradation of piperazine and structurally-related linear and cyclic amines. Biodegradation 5, 83-92.

Enzmann, H., Zerban, H., Kopp-Schneider, A., Loser, E. \& Bannasch, P. (1995). Effect of low doses of N-nitrosomorpholine on the development of early stages of hepatocarcinogenesis. Carcinogenesis 16, 1513-1518.

Franklin, A. (1985). Genetic and biochemical studies of morpholine degradation by a Mycobacterium species. $\mathrm{PhD}$ thesis, University of Wales.

Genthner, B. R. S., Davies, C. L. \& Bryant, M. P. (1981). Features of rumen and sewage sludge strains of Eubacterium limosum, a methanol- and $\mathrm{H}_{2}-\mathrm{CO}_{2}$ utilizing species. Appl Environ Microbiol $42,12-19$.

Häggblom, M. M., Nohynek, L. J., Palleroni, N. J., Kronqvist, K., Nurmiaho-Lassila, E. L., Salkinoja-Salonen, M. S., Klatte, S. \& Kroppenstedt, R. M. (1994). Transfer of polychlorophenol-degrading Rhodococcus chlorophenolicus (Apajalahti et al. 1986) to the genus Mycobacterium as Mycobacterium chlorophenolicum comb. nov. Int J Syst Bacteriol 44, 485-493.

Hamano, T., Mitsuhashi, Y. \& Matsuki, Y. (1981). Glass capillary gas chromatography of secondary amines in foods with flame photometric detection after derivatization with benzenesulfonyl chloride. Agric Biol Chem 45, 2237-2243.

Hormann, K. \& Andreesen, J. R. (1989). Reductive cleavage of sarcosine and betaine by Eubacterium acidaminophilum via enzyme systems different from glycine reductase. Arch Microbiol $153,50-59$.

Knapp, J. S. \& Brown, V. R. (1988). Morpholine biodegradation. Int Biodeterior 24, 299-306.

Knapp, J. S., Callely, A. G. \& Mainprize, J. (1982). The microbial degradation of morpholine. J Appl Bacteriol 52, 5-13.
Knapp, J. S., Emtiazin, G., Yusoff, S. \& Heron, S. T. (1996). The utilization of morpholine as a sole nitrogen source by Gramnegative bacteria. Lett Appl Microbiol 23, 334-338.

Kroppenstedt, R. M. (1985). Fatty acid and menaquinone analysis of actinomycetes and related organisms. Soc Appl Bacteriol Tech Ser 20, 173-199.

Martinis, S. A., Blake, S. R., Hager, L. P. \& Sligar, S. G. (1996). Probing of the heme iron coordination structure of pressureinduced cytochrome P420cam. Biochemistry 35, 14530-14536.

Mazure, N. \& Truffaut, N. (1994). Degradation of morpholine by Mycobacterium aurum MO1. Can J Microbiol 40, 761-765.

Mijos, K. (1978). Cyclic amines. In Kirk-Othmer Encyclopedia of Chemical Technology, vol. 2, pp. 295-308. New York: Wiley.

Mohri, T. (1987). Dietary intakes of nitrosamines precursors. Kyusha Yakugakki Katho 41, 105-112.

Poupin, P., Mazure, N. \& Truffaut, N. (1996). Morpholine degradation by strain Mycobacterium aurum MO1: improvement of cells growth and morpholine degradation rate by cells immobilization. In Immobilized Cells: Basics and Applications, 1st edn, pp. 770-776. Edited by R. H. Wijfells and others. Amsterdam: Elsevier.

Poupin, P., Truffaut, N., Combourieu, B., Besse, P., Sancelme, M., Veschambre, H. \& Delort, A. M. (1998). Degradation of morpholine by an environmental Mycobacterium strain involves a cytochrome P-450. Appl Environ Microbiol 64, 159-165.

Poupin, P., Ducrocq, V., Hallier-Soulier, S. \& Truffaut, N. (1999). Cloning and characterization of the genes encoding a cytochrome P450 (PipA) involved in piperidine and pyrrolidine utilization and its regulatory protein (PipR) in Mycobacterium smegmatis $\mathrm{mc}^{2}$ 155. J Bacteriol 181, 3419-3426.

Rogall, T., Wolters, J., Flohr, T. \& Böttger, E. C. (1990). Towards a phylogeny and definition of species at the molecular level within the genus Mycobacterium. Int J Syst Bacteriol 40, 323-330.

Schuffenhauer, G., Schräder, T. \& Andreesen, J. R. (1999). Morpholine-induced formation of L-alanine dehydrogenase activity in Mycobacterium strain HE5. Arch Microbiol 171, 417-423.

Stackebrandt, E. \& Goebel, B. M. (1994). Taxonomic note: a place for DNA-DNA reassociation and 16S rRNA sequence analysis in the present species definition in bacteriology. Int J Syst Bacteriol 44, 846-849.

Stahl, D. A. \& Urbance, J. W. (1990). The division between fast and slow growing species corresponds to natural relationships among the mycobacteria. J Bacteriol 172, 116-124.

Swain, A., Waterhouse, K. V., Venables, W. A., Callely, A. G. \& Lowe, S. E. (1991). Biochemical studies of morpholine catabolism by an environmental Mycobacterium. Appl Microbiol Biotechnol 35, 110-114.

Tamaoko, J. \& Komagata, K. (1984). Determination of DNA base composition by reversed-phase high-performance liquid chromatography. FEMS Microbiol Lett 25, 125-128.

Testa, B. \& Jenner, P. (1981). Inhibitors of cytochrome P450s and their mechanism of action. Drug Metab Rev 12, 1-117.

Weisburg, W. G., Barns, S. M., Pelletier, D. A. \& Lane, D. J. (1991). $16 \mathrm{~S}$ ribosomal DNA amplification for phylogenetic study. $J$ Bacteriol 173, 697-703.

White, G. F., Russell, N. J. \& Tidswell, E. C. (1996). Bacterial scission of ether bonds. Microbiol Rev 60, 216-232.

Received 22 July 1999; revised 20 December 1999; accepted 31 January 2000. 